\title{
Respons Fisiologis Domba Lokal Dengan Pemberian Biskuit Limbah Sayuran Pasar
}

\author{
Sofyan Hamdani ${ }^{1}$, Aisyah Nurmi ${ }^{2}$, Muharram Fajrin Harahap ${ }^{3}$ \\ ${ }^{1}$ Alumni Fakultas Peternakan Program Studi Peternakan Universitas Muhammadiyah \\ Tapanuli Selatan,e-mail :Sofyanhamdani28@yahoo.co.id \\ ${ }^{2}$ Dosen Program Studi Peternakan Fakultas Peternakan Universitas Muhammadiyah \\ Tapanuli Selatan,e-mail :aisyah.nurmi@um-tapsel.ac.id \\ ${ }^{3}$ Dosen Program Studi AgroteknologiFakultas Pertanian Universitas Muhammadiyah
}

Tapanuli Selatan, e-mail :muharram.fajrin@um-tapsel.ac.id

\begin{abstract}
Abstrak
Domba merupakan ternak ruminansia kecil penghasil daging yang memiliki karakteristik berbulu kasar atau wool, bukan rambut (hair) seperti pada kambing atau sapi. Produksi panas yang tinggi akan menghambat pertambahan bobot badan ternak, maka untuk membantu meningkatkan produktivitas ternak perlu dipertimbangkan manajemen pemberian pakan pada ternak tersebut untuk menghindari beban panas berlebih pada tubuh ternak. Kurangnya lahan budidaya rumput merupakan salah satu faktor penyebab ketersediaan pakan ternak ruminansia, untuk itu di lakukan pemamfaatan limbah sayuran pasar menjadi Biskuit Limbah Sayuran Pasar(BLSP)sehingga mencukupi keperluan pakan ternak.Penelitian telah dilaksanakan di kampus Universitas Muhammadiyah Tapanuli Selatan Kota Padangsidimpuan pada bulan Maret hingga April 2018 dengan tujuan untuk mengetahui respons fisiologis domba lokal dengan pemberian biskuit limbah sayuran pasar menggunakan empat domba lokal dengan perlakuan A0 (BLSP 0\%),A1 ( BLSP 10\%),A3 ( BLSP 30\%),A2 (BLSP 20\%).Rancangan yang digunakan pada penelitian ini adalah rancangan bujur sangkar latin. Parameter yang di amati adalah renpons fisiologis domba (suhu tubuh, denyut jantung, laju respirasi). Dari hasil penelitian menunjukkan hasil yang berbeda nyata terhadap suhu tubuh, denyut jantung, dan laju respirassi domba.Pemberian BLSP memberikan manfaat bagi domba yang dipelihara di daerah tropis.Suplementasi Biskuit Limbah Sayuran Pasar cukup efektif dalam menurunkan tingkat cekaman panas pada domba.Kandang penelitian diusahakan jauh dari kandang pemeliharaan dan tidak saling berhempitan.Pada masa istirahat penelitian tetap diberikan pakan dengan menggunakan BLSP juga.
\end{abstract}

Kata kunci : Domba, BLSP, Respons Fisiologis, RBSL.

\section{PENDAHULUAN}

Usaha peternakan di Indonesia semakin berkembang, salah satunya adalah usaha peternakan domba.Umumnya usaha peternakan domba bertujuan untuk menghasilkan daging guna memenuhi kebutuhan protein hewani masyarakat.Domba merupakan ternak ruminansia kecil yang banyak di pelihara masyarakat Indonesia, baik secara intensif atau ekstensif (digembalakan). Kurangnya perhatian terhadap pakan ternak mengakibatkan produktivitasnya tidak baik. Oleh sebab itu ternak ruminansia seharusnya di pelihara secara intensif agar pemberian pakannya lebih teratur dan dapat meningkatkan produktivitasnya.Kurangnya lahan budidaya rumput merupakan salah satu faktor penyebab ketersediaan pakan ternak ruminansia, karena itu perlu di lakukan pemamfaatan limbah sayuran pasar sehingga mencukupi keperluan pakan ternak. 
Limbah sayuran yang terbuang dan belum dimanfaatkan, menyebabkan jumlah limbah yang berlebihan mengakibatkan polusi.Limbah sayuran dapat diolah menjadi pakan ternak sehingga menghasilkan daging pada ternak dan pupuk organik dari kotoran ternak. Hal tersebut dapat mengakibatkan nilai tambah yang diperoleh akan lebih tinggi sekaligus dapat memecahkan pencemaran lingkungan dan mengatasi kekurangan pakan ternak. Salah satu teknologi yang dapat diterapkan dalam upaya memanfaatkan limbah sayuran pasar yaitu dibuat dalam bentuk biskuit.

Penelitian ini bertujuan untuk mengetahui respons fisiologis domba lokal dengan pemberian biskuit limbah sayuran pasar.

\section{METODE PENELITIAN}

Penelitian ini telah dilaksanakan dikandang aneka ternak (MFE) Fakultas Peternakan Universitas Muhammadiyah Tapanuli Selatan, selama dua bulan mulai Maret hingga April 2018.

\section{Bahan Dan Alata Penelitian}

Ternak domba yang digunakan dalam penelitian ini adalah domba lokal berjenis kelamin jantan umur 1-2 tahun, dengan bobot rata-rata $15,91 \pm 3,69 \mathrm{~kg}$ sebanyak empat(4) ekor. Ternak domba tersebut dipilih berdasarkan keseragaman bobot badan dan umur, serta menunjukkan ciri fisik sehat dan normal (tidak cacat).Domba-domba ini kemudian dipelihara sesuai perlakuan, selama dua (2) bulan.

\section{Kandang Dan Perlengkapan}

Tipe kandang yang digunakan merupakan tipe dinding terbuka, dengan ukuran kandang individu $0,75 \mathrm{~m} \quad \mathrm{x} \quad 1 \mathrm{~m}$ memungkinkan domba melakukan aktivitas lebih banyak,model kandang panggung, lantai kayu dan beratapkan seng.Setiap kandang dilengkapi dengan tempat pakan untuk rumput dan konsentrat serta tempat air minum dari ember plastik hitam kapasitas sepuluh liter.

\section{Pakan Dan Air Minum}

Pakan yang diberikan pada penelitian ini adalah konsentrat, rumput lapan, dan biskuit limbah sayuran pasar dengan komposisi konsntrat $60 \%$, rumput lapan dan BLSP sesuai dengan parameter perlakuan.Rumput lapang diperoleh dari lingkungan kampus Universitas Muhamadiyah Tapanuli Selatan.Dedak dijadikan sebagai konsentrat dan BLPS adalah susunan dari Limbah Sayuran pasar kering yang sudah dicampurkan dengan bahan lainnya.Air minum diberikan pada siang hari secara adlibitum.

\section{Obat-Obatan}

Obatcacing kalbajen dengan dosis 375 mg/ $45 \mathrm{~kg}$ BB untuk menghilangkan parasit dalam saluran pencernaan pada awal penelitian.

\section{Rancangan Penelitian}

Penelitian ini dilaksanakan menggunakan Rancangan Bujur Sangkar Latin (4x4). Dengan empat (4) taraf penelitian : $\mathrm{A} 0=$ Tanpa pemberian BLSP, A1 = dengan pemberian BLSP $10 \%, \mathrm{~A} 2=$ dengan pemberian BLSP 20\%, A3 = dengan pemberian BLSP 30\%.

Model matematiaka RBSL (Adji Sastrosupadi, 2000) :

$$
\mathrm{Y}_{\mathrm{ijk}}=\mu+\mathrm{T}_{\mathrm{i}}+\mathrm{B}_{\mathrm{j}}+\mathrm{K}_{\mathrm{k}}+\varepsilon_{\mathrm{ijk}}
$$

\section{Parameter Penelitian}

1. Suhu tubuh;Suhu rektal diukur dengan memasukkan termometer digital ke rektum domba selama \pm 1 menit. Kemudian dihitung suhu tubuhnya berdasarkan rumus Schmidt-Nielsen (1997):

$$
\mathrm{St}=0.86 \mathrm{Sr}+0.14 \mathrm{Sk}
$$

Keterangan: $\mathrm{St}=$ suhu tubuh

$\mathrm{Sr}=$ suhu rektal

Sk $=$ suhu permukaan kulit

2. Laju respirasi; Penghitungan laju respirasi dilakukan dengan cara menghitung frekuensi napas selama satu menit. Penghitungan diulang sebanyak tiga kali dalam setiap pengambilan data. Data frekuensi respirasi adalah rata-rata dari ketiga penghitungan (Schmidt-Nielsen ,1997). 
3. Denyut jantung;Pengukuran denyut jantung dilakukan dengan mengukur jumlah detakan di bagian dada kiri atas dekat tulang axilla sebelah kiri dengan menggunakan stetoskop. Penghitungan denyut jantung dengan cara menghitung jumlah denyutan jantung selama satu menit. Hitungan diulang sebanyak tiga kali dalam setiap pengambilan data denyut jantung. Data denyut jantung adalah rata-rata dari ketiga penghitungan (Schmidt-Nielsen, 1997).

\section{HASIL PENELITIAN}

\section{Kondisi Lingkungan Penelitian}

Tempat yang digunakan untuk penelitian berada di wilayah kampus Universitas Muhammadiyah Tapanuli Selatan Kota Padangsidimpuan. Kandang penelitian berada dilahan praktikum Fakultas Peternakan, kandang terdiri atas kandang individu dan kandang koloni dengan kapasitas tampung untuk enam sampai sepuluh ekor domba untuk pemeliharaan domba.

Tabel 4.1 Rekapitulasi Data Selama Penelitian sebesar 20\% dari kebutuhan pakan domba lokal setiap hari.

Tipe kandang yang digunakan merupakan tipe dinding terbuka, dengan ukuran kandang individu $0,75 \mathrm{~m} \quad \mathrm{x} \quad 1 \mathrm{~m}$ memungkinkan domba melakukan aktivitas lebih banyak, model kandang panggung, lantai kayu dan beratapkan seng.Setiap kandang dilengkapi dengan tempat pakan untuk rumput dan konsentrat serta tempat air minum dari ember plastik hitam kapasitas sepuluh liter.

\section{Kondisi Ternak}

Temak yang dipilih adalah domba lokal jantan empat (4) ekor yang sehat dan normal (tidak cacat) dengan bobot badan awal domba satu (D1) $28 \mathrm{~kg}$; domba dua (D2) 28 kg; domba tiga (D3) 27 kg; domba empat (D4) $29 \mathrm{~kg}$. Satu minggu sebelum pemberian perlakuan pakan terhadap domba lokal dilakukan pemberian obat cacing kalbajen dengan dosis $375 \mathrm{mg} / 45$ kg BB untuk menghilangkan parasit dalam saluran pencernaan, kemudian dilakukan penimbangan untuk mengetahui bobot badan awal.

\begin{tabular}{|c|c|c|c|c|c|c|c|c|c|}
\hline \multirow[b]{2}{*}{ Perlakuan } & \multicolumn{3}{|c|}{ Suhu tubuh } & \multicolumn{3}{|c|}{ Denyut jantung } & \multicolumn{3}{|c|}{ Laju respirasi } \\
\hline & Pagi & Siang & Malam & Pagi & Siang & Malam & Pagi & Siang & Malam \\
\hline A0 & $37.77^{c}$ & $38.04^{b}$ & $37.55^{\mathrm{a}}$ & $70.75^{a}$ & $79.25^{\text {tn }}$ & $70.75^{\text {tn }}$ & $21.50^{a}$ & $29.25^{\text {tn }}$ & $28.00^{\text {tn }}$ \\
\hline A1 & $37.93^{c}$ & $34.64^{\mathrm{a}}$ & $37.28^{a}$ & $67.00^{a}$ & $70.00^{\text {tn }}$ & $75.25^{\mathrm{tn}}$ & $21.25^{a}$ & $22.75^{\mathrm{tn}}$ & $31.50^{\mathrm{tn}}$ \\
\hline A2 & $37.12^{\mathrm{a}}$ & $38.40^{b}$ & $37.39^{a}$ & $67.00^{a}$ & $66.50^{\text {tn }}$ & $72.00^{\text {tn }}$ & $21.50^{a}$ & $25.50^{\text {tn }}$ & $28.75^{\text {tn }}$ \\
\hline A3 & $37.17^{\mathrm{ab}}$ & $38.02^{b}$ & $37.02^{a}$ & $71.00^{a}$ & $81.50^{\text {tn }}$ & $76.75^{\mathrm{tn}}$ & $23.25^{\mathrm{a}}$ & $32.25^{\mathrm{tn}}$ & $28.00^{\text {tn }}$ \\
\hline
\end{tabular}

Dari tabel diatas dapat lihat bahwa suhu tubuh pada pagi hari dengan perlakuan A0, A1, A2, dan A3 tidak menunjukkan hasil yang signifikan.Semua perlakuan menunjukkan hasil yang nyata, hanya perlakuan A0 dan A1 saja yang tidak membedakan. Suhu tubuh tertinggi terdapat pada perlakuan A3 dengan pemberian BLSP sebesar 30\% dari kebutuhan pakan domba lokal setiap hari. Suhu tubuh terendah terdapat pada perlakuan A2 dengan pemberian BLSP
Suhu tubuh domba pada siang dengan pemberian BLSP tidak menunjukkan pengaruh yang membedakan antara perlakuan A0, A2, dan A3 tetapi memberikan pengaruh yang nyata terhadap perlakuan A1. Suhu tubuh tertinggi terdapat pada perlakuan A2 dengan pemberian BLSP sebesar 20\% dari kebutuhan pakan domba lokal setiap hari. Suhu tubuh terendah terdapat pada perlakuan A1 dengan pemberian BLSP sebesar $10 \%$ dari kebutuhan pakan domba lokal setiap hari. 
Suhu tubuh domba pada malam dengan pemberian BLSP tidak menunjukkan pengaruh yang membedakan antara perlakuan A0, A1, A2, dan A3 padahal pada analisis sidik ragam terdapat pengaruh yang nyata.Suhu tubuh tertinggi terdapat pada perlakuan A0 dengan pemberian BLSP sebesar $0 \%$ dari kebutuhan pakan domba lokal setiap hari. Suhu tubuh terendah terdapat pada perlakuan A3 dengan pemberian BLSP sebesar 30\% dari kebutuhan pakan domba lokal setiap hari.

Denyut jantung domba pada pagi hari dengan pemberian BLSP tidak menunjukkan pengaruh yang membedakan antara perlakuan A0, A1, A2, dan A3 padahal pada analisis sidik ragam terdapat pengaruh yang nyata.Denyut jantung tertinggi terdapat pada perlakuan A3 dengan pemberian BLSP sebesar 30\% dari kebutuhan pakan domba lokal setiap hari. Denyut jantung terendah terdapat pada perlakuan A1 dengan pemberian BLSP sebesar $10 \%$ dan A2 dengan pemberian BLSP sebesar 20\% dari kebutuhan pakan domba lokal setiap hari.

Denyut jantung domba pada siang hari dengan pemberian BLSP berpengaruh tidak nyata.Denyut jantung tertinggi terdapat pada perlakuan A3 dengan pemberianBLSP sebesar $30 \%$ dari kebutuhan pakan domba lokal setiap hari. Denyut jantung terendah terdapat pada perlakuan A2 dengan pemberian BLSP sebesar 20\% dari kebutuhan pakan domba lokal setiap hari.

Denyut jantung domba pada malam hari dengan pemberian BLSP berpengaruh tidak nyata.Denyut jantung tertinggi terdapat pada perlakuan A3 dengan pemberian BLSP sebesar 30\% dari kebutuhan pakan domba lokal setiap hari. Denyut jantung terendah terdapat pada perlakuan A0 dengan pemberian BLSP sebesar $0 \%$ dari kebutuhan pakan domba lokal setiap hari.

Laju respirasi domba pada pagi hari dengan pemberian BLSP tidak menunjukkan pengaruh yang membedakan antara perlakuan A0, A1, A2, dan A3 padahal pada analisis sidik ragam terdapat pengaruh yang nyata. Laju respirasi tertinggi terdapat pada perlakuan A3 dengan pemberian BLSP sebesar 30\% dari kebutuhan pakan domba lokal setiap hari. Laju respirasi terendah terdapat pada perlakuan A0 dengan pemberian BLSP sebesar 0\% dan A2 dengan pemberian BLSP sebesar 20\% dari kebutuhan pakan domba lokal setiap hari.

Laju respirasi domba pada siang hari dengan pemberian BLSP berpengaruh tidak nyata.Laju respirasi tertinggi terdapat pada perlakuan A3 dengan pemberian BLSP sebesar 30\%. Laju respirasi terendah terdapat pada perlakuan A2 dengan pemberian BLSP sebesar 20\%.

Laju respirasi domba pada malam hari dengan pemberian BLSP berpengaruh tidak nyata.Laju respirasi tertinggi terdapat pada perlakuan A1 dengan pemberian BLSP sebesar 10\%. Laju respirasi terendah terdapat pada perlakuan A0 dan A3 dengan pemberian BLSP sebesar $30 \%$ dari kebutuhan pakan domba lokal setiap hari.

\section{KESIMPULAN}

Pemberian Biskuit Limbah Sayuran Pasar terhadap respons fisiologis dombalokal sudah tergolong baik.Pemberian BLSP memberikan manfaat bagi domba yang dipelihara di daerah tropis.Suplementasi Biskuit Limbah Sayuran Pasar cukup efektif dalam menurunkan tingkat cekaman panas pada domba.Pemberian Biskuit Limbah Sayuran Pasar dapat berpengaruh terhadap respons fisiologis domba lokal jantan.

\section{DAFTAR PUSTAKA}

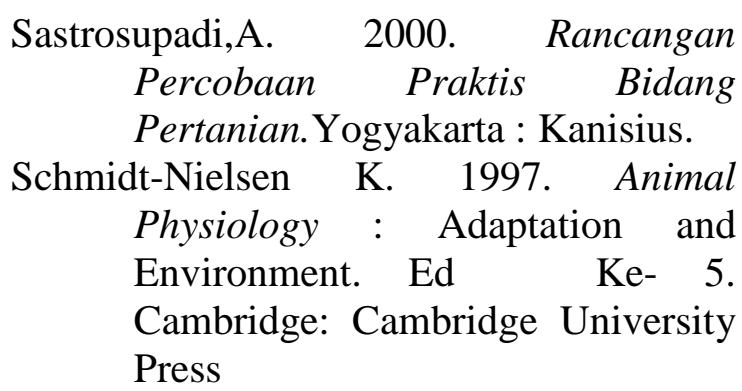

